\title{
Biochemical Characterization of Collagen Extracted from the Swim Bladder of Catfish (Bagre panamensis)
}

\author{
Lopez $S$. \\ Salguero A. \\ Vargas $A$. \\ Zavala A.
}

Facultad de Ciencias Pecuarias, ESPOCH, Riobamba, Ecuador

Doi: 10.19044/esj.2018.v14n30p1 URL:http://dx.doi.org/10.19044/esj.2018.v14n30p1

\begin{abstract}
In the present investigation, the extraction and subsequent characterization of the collagen in the swim bladder of catfish was developed, for which a total of twelve experimental units were analyzed, distributed in three samples with four repetitions per analysis distributed under a completely randomized design with a $0,05 \%$ of significance, the size of the experimental unit $200 \mathrm{~g}$ of lyophilized collagen. Protein, minerals, water, $\mathrm{pH}$, hydroxyproline were then quantified in addition to the microbiological assays. The results obtained correspond to $76.86 \%$ of protein, $9.02 \%$ of humidity, $14.12 \%$ of ash, while for $\mathrm{pH} 4.55$, hydroxyproline $44,08 \%$ and ausence of UFC/g were reported. It is determined that it can be used in food formulations to improve the texture due to its hydroxyproline content.
\end{abstract}

Keywords: Collagen, Hydroxyproline, swim bladder

\section{Introduction}

Blue catfish (B. panamensis) is a species that lives in marine waters, reaches $38 \mathrm{~cm}$ in total length and is usually captured with nets and hooks. Its body is narrow, straight and steep dorsal profile, broad and flat snout, arched mouth, fine and conical teeth, mandibular teeth arranged in a transverse band in the anterior part of the palate. (Álvarez, 2012).

Kobelkowsky \& Castillo, (1995), state that the swim bladder of the catfish is formed by a single heart-shaped chamber where the pneumatic conduit starts from the right side of the esophagus and connects to the ventral surface of the bladder, continuing internally in the form Groove It is mentioned that collagen and gelatin obtained from swim bladders have important technological applications. While for culinary use it is used in the preparation of an exotic dish originating from the Asian continent. It is a soup 
called "Seen Kow" that claim to have nutraceutical properties such as lowering cholesterol, improving circulation and even rejuvenate the skin, due to its collagen content.

According to (Voet \& Voet, 2006) it is mentioned that collagen is present in multicellular animals defining it as an extracellular protein organized in soluble fibers of high tensile strength (CECOPESCA, 2012); that form long chains and have a secondary structure in the form of helical winding (Torres, et al, 2008).

Usually the sources of collagen in industry are obtained from the skin and bones of cattle, pigs and poultry; These common sources present certain difficulties and are inappropriate for many religious and ethnic groups due to socio-cultural prohibitions (De la torre, 2013).

An alternative source of collagen is fish, several investigations in various countries, describe the preparation of collagen from the skin of aquatic species such as trout (Martínez et al., 2011), and Coryphaena hippurus (Romero, 2016), tendon of cattle (Gomez, Piña, \& Rodriguez, 2011), bone, fins and the viscera of fish are attracting attention for being an important source of minerals, proteins and fat for use in various products (FAO, 2014).

Abad, (2015) Indicates that collagen contains approximately $30 \%$ glycine, has a compact structure, while $25 \%$ of its composition responds to 2 special amino acids: hydroxyproline and hydroxylysine that provide rigidity to the helix. The presence of hydroxyproline is often used as an analytical criterion to evaluate the amount of collagen present in the product, being synonymous with quality as the component differs from one species to another and the tissue from which it is isolated. (Romero, 2016).

\section{Material and Methods}

For the development of the research, the extraction of the collagen was previously carried out by means of a chemical-enzymatic method starting from the fresh swim bladder of the catfish (Bagre panamensis). The collagen obtained in liquid form was freezed at a temperature of $-10^{\circ} \mathrm{C}$ to finally lyophilize it.

Tests were carried out for quantification of minerals, moisture and crude protein, as cited by the (AOAC, 2005). For the determination of $\mathrm{pH}$, the procedure described by (INEN 820, 1982) is used, while the content of hydroxyproline was carried out according to the method of Woessner, $\mathrm{J}$ (1961). The microbiological tests were performed on the raw material obtained, determining total coliforms, fecal coliforms, yeasts and molds CFU / g (Minnesota Mining and Manufacturing Company 3M, 2000). 


\section{Results and Discussion}

The results of the bromatological analysis of collagen are reported in Table 1.

Table 1. Biochemical composition of collagen of the bagre swelling bladder

(B. panamensis).

\begin{tabular}{ll} 
Variables & Media \\
\hline Crude protein & $\mathbf{7 6 . 8 6 \%}$ \\
Water & $\mathbf{9 . 0 2 \%}$ \\
Ash & $\mathbf{1 4 . 1 2 \%}$ \\
pH & $\mathbf{4 . 5 5}$ \\
Hidroxiproline & $\mathbf{4 4 . 4 8 \%}$ \\
\hline
\end{tabular}

\section{Crude protein (\%)}

The average protein content determined by the Kjeldahl method, presented a coefficient of variation of $1.15 \%$ among the analyzed samples, these result are in accordance with what Solari \& Córdova mentions, (2015) the collagen extracted from processing waste of Engraulis ringens presents $87.6 \%$ of protein; Martínez et al. (2011) also indicates that a gelatin made from trout skin has $80.41 \%$ protein.

It is necessary to consider that the protein content can vary due to several factors such as: the species of the fish, the season of the year, the byproduct to be used as raw material as well as the type of food consumed during its life.

\section{Water content}

Likewise, the collagen samples were analyzed with the following average values among the replicates, a percentage of $17.14 \%$ being determined as coefficient of variation, which could be due to the same extraction process and lyophilization time. Solari \& Córdova, (2015), report that the humidity of the collagen of fish waste is $8.0 \%$ and the collagen obtained from bovine waste is $11 \%$ according to (Peralta et al., 2012), finding the product in value that limit the microbial development considering that the water content is of vital importance in the final quality of the product.

\section{Mineral content}

The mineral content was obtained by analyzing four samples with a coefficient of variation of $4.92 \%$. These results vary with what indicates Solari \& Córdova, (2015) with respect to the collagen obtained from residues of Engraulis ringens that presents $0.7 \%$ and Martínez et al., (2011), where it is also indicated that the gelatin extracted from trout skin has a $3.78 \%$ ash, differ with the values obtained in this study, then proceeded to quantify the mineral profile, obtaining that $4.7 \%$ corresponds to the calcium proper nature of the raw material with which job. 


\section{Determination of $\mathbf{p H}$}

Kaewdang, Benjakul, Kaewmanee, \& Kishimura, (2014), express that the collagen extracted from swim bladders of Yellowfin tuna has a pH of 6.05, also mentions that collagen from skins of different fish are found with a value of 4.72 (collagen of striped catfish), 6.40 (collagen adorned with bream) and 6.21 (collagen of bamboo shark), however, they differ with what Quintero \& Zapata (2017) exposes, regarding the $\mathrm{pH}$ of the collagen obtained from fish scales 3.12, skin 3.50 and spines with a $\mathrm{pH}$ of 3.02 .

Although all $\mathrm{pH}$ values show acid, the variation in $\mathrm{pH}$ between the collagens of many fish species can be caused by the slight difference in their amino acid composition and the distribution in the surface of protein.

\section{Hydroxyproline content}

Being the hydroxyproline directly proportional to the protein content and the amino acid in greater quantity present in the collagen. The values reported in the study have an average of $44.48 \%$ of Hydroxyproline in the collagen extracted from swim bladder of catfish, the same ones that differ from the values announced by Quintero \& Zapata, (2017) are: $0.23 \%$ in scales and $0.30 \%$ in skin and Torres et al., (2008), states that the collagen of the squid tentacle has $2.84 \%$ Hydroxyproline.

A study conducted by Fernandez et al., (2008) about the characterization of collagen obtained from swim bladders of yellowfin tuna, which has a range of 102 to $854 \mathrm{ug} / \mathrm{g}$ of Hpro present in collagen, the same as indicates that catfish swim bladder collagen is within this range with a value of $145.67 \mathrm{ug} / \mathrm{g}$.

In addition, the microbiological tests carried out for total Coliforms, yeasts and molds show ausence of them, guaranteeing the safety of the product.

\section{Conclusion}

Collagen extracted from the swim bladder of catfish presented a crude protein content of $76.86 \%$, water content $9.02 \%$, ash $14.12 \%, \mathrm{pH} 4.55$, hydroxyproline $44.48 \%$. In the microbiological analysis, the absence of CFU / g microorganisms in lyophilized collagen samples was verified. The use of this raw material is recommended in the possible elaboration of food derivatives due to its content of hydroxyproline.

\section{References:}

1. Abad, C. (2015). Suplementos de colágeno y efecto en el tratamiento de lesiones articulares.

2. Álvarez, Á. (2012). "Alternativa de aprovechamiento para el chiguil (Bagre panamensis); especie de bajo valor comercial“. Universidad 
Autónoma de baja California Sur.

3. AOAC. (2005). Official Methods for Analysis of the Association of Official Analytical Chemists. (14th editi). Arlington.

4. CECOPESCA. (2012). GUÍA PARA EL APROVECHAMIENTO DE LOS SUBPRODUCTOS DE PESCADO PARA LA OBTENCIÓN DE PRODUCTOS FUNCIONALES Y BIOACTIVOS. España.

5. De la torre, G. (2013). Obtencion de colageno y su efecto como capa protectora edible utilizando nisina como preservante en productos carnicos y quesos. Universidad de Guayaquil.

6. Fernandes, R., Couto, R., Paschoal, C., Rohling, J., \& Bezerra, C. (2008). Collagen films from swim bladders : Preparation method and properties. Science Direct, 17. https://doi.org/10.1016/j.colsurfb.2007.09.011

7. Gomez, K., Piña, C., \& Rodriguez, N. (2011). Obtención y caracterización de colágena tipo I a partir de tendón bovino. Sociedad Mexicana de Ciencia Y Tecnología de Superficies Y Materiales, 24(4), 137-140.

8. INEN 820. AGENTES TENSOACTIVOS. DETERMINACION DEL pH., $818 \S$ (1982). Ecuador.

9. Kaewdang, O., Benjakul, S., Kaewmanee, T., \& Kishimura, H. (2014). Characteristics of collagens from the swim bladders of yellowfin tuna ( Thunnus albacares ). FOOD CHEMISTRY, 155, 268. https://doi.org/10.1016/j.foodchem.2014.01.076

10. Kobelkowsky, A., \& Castillo, M. (1995). Sistema Digestivo y alimentacion de los bagres (Pisces:Ariidae) del Golfo de Mexico. Hidrobiologica. Mèxico: Universidad Autònoma Metropolitana, Unidad Iztapalapa.

11. Martínez, G., Uresti, R. M., Ramirez, J. A., \& Velazquez, G. (2011). Extracción y caracterización de algunas propiedades fisicoquímicas de gelatina de piel de trucha. Revista Ciencia U.A.Q., 4(2), 26-34.

12. Minnesota Mining and Manufacturing Company. (2000). Placas Petrifilm 3M Placas Petrifilm para el recuento de Coliformes (Vol. 69). St. Paul, Minnesota,.

13. Peralta, C., Rivera, N., \& Gualdrón, L. (2012). a partir de los cascos de bovinos. Revista Épsilon, 59-69.

14. Quintero, J., \& Zapata, J. (2017). Optimización de la Extracción del Colágeno Soluble en Ácido de Subproductos de Tilapia Roja ( Oreochromis spp ) mediante un Diseño de Superficie de Respuesta Optimization of the Extraction of Acid-Soluble Collagen from Byproducts Red Tilapia ( Oreochromis, 28(1), 113. https://doi.org/10.4067/S0718-07642017000100011

15. Romero, R. (2016). OBTENCIÓN DE GELATINA DE PIEL DE 
PERICO (Coryphaena hippurus) Y CARACTERIZACIÓN DE SUS PROPIEDADES FISICOQUÍMICAS". UNIVERSIDAD NACIONAL AGRARIA LA MOLINA.

16. Solari, A., \& Córdova, J. (2015). Extracción de colágeno proveniente de residuos del procesamiento de Engraulis ringens ANCHOVETA. Ciencia E Investigación, 18(2), 66.

17. Torres, W., Pacheco, R., Sotelo, R., Rouzaud, O., \& Ezquera, J. (2008). CARACTERIZACIÓN PARCIAL DEL COLÁGENO EXTRAÍDO A PARTIR DEL MANTO, ALETA Y TENTÁCULOS DE CALAMAR GIGANTE (Dosidicus gigas). Ciencia Y Tecnología Alimentaria, 9.

18. Voet, D., \& Voet, J. (2006). Bioquímica. (E. M. P. S.A, Ed.) (Tercera ed). Buenos Aires. 